\title{
Handling Slum Settlement Based on Community Participation and Socio-Cultural Change: Perspective of Sustainable Development of Makassar City, Indonesia
}

\author{
Batara Surya ${ }^{A}$, Agus Salim ${ }^{A}$, Hernita Hernita ${ }^{B}$, Seri Suriani ${ }^{C}$, \\ Herminawaty Abubakar ${ }^{C}$, Haeruddin Saleh ${ }^{D}$ \\ Received: July 06, 2021 | Revised: October 12, 2021 | Accepted: October 13, 2021 \\ doi: 10.5937/gp25-33038
}

\begin{abstract}
Urbanization in the dynamics of development in Makassar City has an impact on increasing population, poverty, social change, acculturation of community culture, marginalization, differences in lifestyle, socio-economic inequality, complexity of space use, slum settlements, and a decrease in environmental quality. This study aims to analyze: (1) Community participation and socio-cultural changes work as determinants of handling urban slum settlements, (2) The influence of community participation, improving the quality of infrastructure, improving the quality of the environment, and changing the sociocultural community on the sustainability of city development, and (3) Formulate a model for handling slum settlements, community participation, and community social culture towards the sustainability of urban development. This study uses a qualitative-quantitative approach sequentially. Data were obtained through observation, Focus Group Discussions (FGD), surveys, and documentation. The results showed that community participation, improving the quality of infrastructure, improving the quality of the environment, and socio-cultural changes simultaneously affected the sustainability of Makassar City development. Furthermore, the implementation of the program to improve the quality of slums followed by community participation and accompanied by socio-cultural changes will encourage the creation of equitable development, improve the quality of slum settlements, and improve community welfare towards the creation of social cohesion, increase community productivity, and harmonization of community life towards sustainability development of Makassar City, Indonesia.
\end{abstract}

Keywords: Community Participation; Slums Settlements; Socio-Cultural Change; Sustainable Development

A University Bosowa, Faculty of Engineering, Department of Urban and Regional Planning, Makassar City, 90231, Indonesia; batara.surya@universitasbosowa.ac.id; asalim.plan@gmail.com

B STIM Lasharan Jaya, Department of Economic, Makassar City, 90231, Inonesia; hernita@stimlasharanjaya.ac.id

C University Bosowa, Faculty of Economic and Bussines, Department of Economic management, Makassar City, 90231, Indonesia; seri.suriani@universitasbosowa.ac.id; herminawati.abubakar@universitasbosowa.ac.id

D University Bosowa, Faculty of Economic and Bussiness, Department of Regional Economic, Makassar City, 90231, Indonesia; haeruddin@universitasbosowa.ac.id

* Corresponding author: Batara Surya; e-mail: batara.surya@universitasbosowa.ac.id 
Urbanization in the dynamics of urban development in developing countries has an impact on increasing the need for land to meet the needs for housing development and urban infrastructure. This condition is a challenge for the community and government in meeting the needs of housing, infrastructure, transportation, and other socio-economic activities (Gong, et al., 2014; Zeng, et al., 2017; Pratomo, et al., 2020). The fairly, high trend of population growth is closely related to land use change, the complexity of spatial use, community poverty and slum settlements. The complexity of spatial use, poverty, and the development of slum settlements are positively associated with a decrease in environmental quality (Surya, et al., 2020a). Slum settlements are, also places where the cultural mix of different communities, so that their handling will require empowerment support that is oriented towards improving the welfare and independence of the community (UNHabitat, 2003; Surya, et al., 2020b).

The community involved in the development process is a reflection, of community participation in planning and acting as the main actor in implementation program. Community involvement in program planning and implementation, namely at the formulation, design, implementation, and post-implementation stages as a unitary development system (Sindleryova, et al., 2019). This means that the community will participate if the implementation of the development program is in accordance with the aspirations and needs of the community itself. Thus, the implementation of strategic policies and programs will require cooperation and participation of development actors (Friesen, et al., 2018). Furthermore, the community will critically understand the problem, the need for handling, propose solutions, and participate in program implementation (Samper, et al., 2020; Surya, et al., 2020c). This means that community participation coupled with socio-cultural changes and being responsible for program implementation will accelerate the handling of slum settlements towards improving environmental quality, reducing poverty, and achieving community homogenization and sustainable development of Makassar City.

\section{Study area}

The geographical location of the area, Makassar City is at the coordinates $119^{\circ} 18^{\prime} 27.97^{\prime \prime}-119^{\circ} 32^{\prime} 31.03^{\prime \prime}$ East Longitude and $5^{\circ} 00^{\prime} 30,18^{\prime \prime}-5^{\circ} 14^{\prime} 6,49^{\prime \prime}$ South latitude.
Slum settlements in Makassar City are distributed in 127 locations and occupy an area of 729 ha with three typological categories, namely (i) slums on the wa-

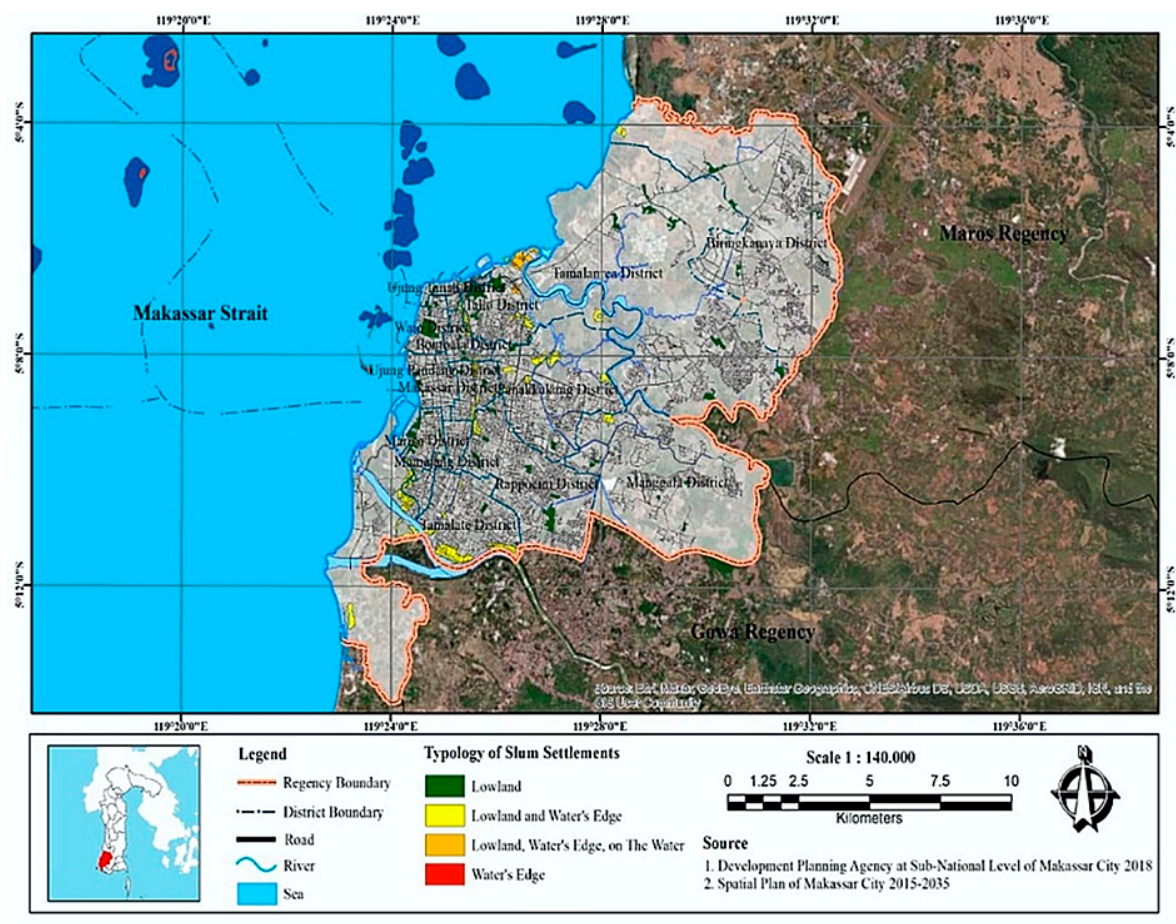

Figure 1. The location of the slum settlements in Makassar City as the object of study 
ter, (ii) slums on the waterfront, and (iii) slums in the lowlands. Several things can be explained related to the data, among others: (1) Slum settlements that develop based on their dominant size are located in the Tamalate District occupying an area of 177,91 ha or 24.4\%; (2) Slum settlements that have developed in the Tallo District area occupy an area of 119.1 ha or $16.3 \%$; (3) Developing slum settlements in the area of Panakkukang District covering an area of 68.95 ha or 9.5\%; (4) Developing slum settlements in the area of Rappocini District covering an area of 59.74 ha or 8.2\%; (5) Slum settlements that developed in the Tamalanrea District covering an area of 46.21 ha or $6.3 \%$, and (6) Slum settlements that developed in the Biringkanaya
District covering an area of 43.13 ha or $5.9 \%$ (BPS Makassar City, 2020). The selection of study locations was based on the following considerations: (1) Characteristics and typology of developing slum settlements have different urgency for handling in terms of physical, economic, and social aspects; (2) The complexity of spatial use due to the existence of slum settlements has a positive association with environmental quality degradation; (3) Slum settlements that develop on illegal land are dominated by the urban poor; and (4) The level of income and work orientation of the community shows differences in terms of community participation in handling slum settlements. Furthermore, the research location is presented in Figure 1 below.

\section{Material and Method}

\section{Method of Collecting Data}

\section{Observation}

Observations in this study were used for data needs, including: (1) Community participation data, namely community involvement and community contributions, both individually and institutionally in the implementation of slum settlement programs; (2) The environmental quality of slums is related to the potential sources of pollution and their impacts; (3) the quality of the infrastructure that has been carried out in the field, and (4) the socio-cultural changes of the community, in relation to the social system and cultural patterns of the community in handling slum settlements. Furthermore, the instruments used in the observations were field notes, a base map of the location of slums, periodic notes, and checklists. The data obtained through the researcher's observations are then used to describe the role of the community and the socio-cultural changes of the community in the slum settlement program that has been implemented.

\section{Focus Group Discussion (FGD)}

The Focus Group Discussion (FGD) in this study was conducted six times with 15-20 participants for each implementation. FGD is a systematic process of collecting data and information about a very specific problem through group discussions (Irwanto, 2006). The FGD stages carried out in this study included: (1) Determining the number of groups related to the topics discussed, in this case each group representing the characteristics and typology of slum settlements; (2) Determination of group composition, in this case based on the function and role of each community group; (3) Determination of the location of the FGD implementation, at a neutral location; (4) Seating arrangements to facilitate in- teractive communication, and (5) Appointing facilitators who represent community elements. The focus of the FGD implementation was used to capture the aspirations and views of the community related to six important things, namely (i) the mechanism applied in the formulation of the slum settlement planning program, (ii) program implementation, (iii) evaluation of the program implementation of the relationship with the condition of the residential environment, (iv) ) the value of the benefits obtained after the implementation of the program, (v) the contribution of the community in the implementation of the program, and (vi) the role of community institutions in the implementation of the program. The main topics formulated in the FGD implementation were community participation in handling slum settlements, and community involvement for each process and stage. Furthermore, the FGD process was also used to assess the socio-cultural changes of the community related to attitudes, knowledge, and behavior after the slum settlement program was implemented. The results of the FGD implementation by researchers were used to analyze community involvement at the planning, implementation, evaluation and monitoring stages as well as the value of the benefits obtained by the community in handling slum settlements in Makassar City.

\section{Questionnaire}

Data collection through questionnaires was carried out from June to November 2020. Questionnaires were distributed to 127 slum locations spread across 15 districts in Makassar City. Filling out the questionnaire in this study was guided by researchers and enumerators. Respondents who filled out the questionnaire in this study were determined based on the following criteria: (i) facilitators involved in handling slum settlements, (ii) administrators of commu- 
nity institutions, (iii) community leaders, (iv) district and village government officials, and (iv) community living in slums. Furthermore, the determination of respondents in this study used a purposive sampling technique determined by the researcher based on certain characteristics. Withdrawal of samples refers to Cochran (1977). Furthermore, the formulations used in determining respondents are as follows.

$$
\mathrm{n}=\frac{\frac{\mathrm{t}^{2} \mathrm{pq}}{\mathrm{d}^{2}}}{1 \frac{1}{\mathrm{~N}}\left(\frac{\mathrm{t}^{2} \mathrm{pq}}{\mathrm{d}^{2}}-1\right)}
$$

Where $\mathrm{n}$ is the minimum number of samples, $\mathrm{N}$ is the population size, $t$ is the level of confidence (used 0.95 so that the value of $t=1.96)$, $d$ is the level of error (used 0.05), $\mathrm{p}$ is the proportion of certain characteristics (group) $\mathrm{q}$ is $1-\mathrm{p}$, and 1 is a constant number. The number of samples in this study was set at 400 samples.

\section{Data Analysis Method}

In order, to answer the second question, namely how big is the influence of community participation, improving the quality of infrastructure, improving the quality of the environment, and changing the sociocultural community on the sustainability of city development. Furthermore, to examine the effect of community participation $\left(\mathrm{X}_{1}\right)$, improving the quality of infrastructure $\left(\mathrm{X}_{2}\right)$, improving the quality of the environment $\left(\mathrm{X}_{3}\right)$, socio cultural change $\left(\mathrm{X}_{4}\right)$, on the sustainability of city development $(\mathrm{Y})$, referring to the questionnaire data obtained in the field, then analyzed using multiple regression methods and correlation analysis. The analysis formula used is as follows.

$$
\mathrm{Y}=\mathrm{a}+\mathrm{b}_{1} \mathrm{X}_{1}+\mathrm{b}_{2} \mathrm{X}_{2}+\mathrm{b}_{\mathrm{n}} \mathrm{X}_{\mathrm{n}}
$$

$$
r_{x y}=\frac{\sum x y}{\sqrt{\left(\sum x^{2}\right)\left(\sum y^{2}\right)}}
$$

Where $\mathrm{Y}$ is the dependent variable, $\mathrm{a}$ is the constant $b_{1}, b_{2}, b_{n}$ is the regression coefficient $X_{1}, X_{2}, X_{n}$, is the independent variable. Correlation analysis in this study uses product moment correlation, where rxy is the correlation coefficient between $\mathrm{X}$ and $\mathrm{Y}, \mathrm{x}$ is the deviation from the mean for the value of the variable $\mathrm{X}, \mathrm{y}$ is the deviation from the mean for the value of the variable $\mathrm{Y}, \mathrm{xy}$ is the sum of the multiplications between the values of $\mathrm{X}$ and $\mathrm{Y}, \mathrm{x}^{2}$ is the square of the $\mathrm{x}$ value, and $\mathrm{y}^{2}$ is the square of the $\mathrm{y}$ value. Furthermore, in order, to how is the model for handling slum settlements, community participation, and socio-culture of the community towards the sustainability of urban development, using SEM analysis. The application of SEM in this study refers to several exogenous variables, including: First, the construction of slum settlement management is measured by indicators, namely improving the quality of environmental roads $\left(\mathrm{X}_{1}\right)$, environmental drainage $\left(\mathrm{X}_{2}\right)$, clean water services $\left(\mathrm{X}_{3}\right)$, waste water and sanitation. $\left(\mathrm{X}_{4}\right)$, and waste management $\left(\mathrm{X}_{5}\right)$. Second, the construct of community participation is measured by indicators, namely community participation $\left(\mathrm{X}_{6}\right)$, involvement in program formulation $\left(\mathrm{X}_{7}\right)$, contribution of ideas $\left(\mathrm{X}_{8}\right)$, program implementation $\left(\mathrm{X}_{9}\right)$, and responsibility for program outcomes $\left(\mathrm{X}_{10}\right)$. Furthermore, the constructs of endogenous latent variables include: (1) The socio-cultural latent variables of the community are measured by indicators, namely attitudes $\left(\mathrm{y}_{1}\right)$, knowledge $\left(\mathrm{y}_{2}\right)$, and behavior $\left(\mathrm{y}_{3}\right)$; (2) The latent variables of urban development sustainability, measured by indicators, namely environmental $\left(\mathrm{y}_{4}\right)$, economic $\left(\mathrm{y}_{5}\right)$, and social $\left(\mathrm{y}_{6}\right)$. The SEM analysis method uses the following formulation:

$$
\begin{aligned}
& \eta=\alpha+B \eta+\Gamma \xi+\zeta \\
& \eta-B \eta=\alpha+\Gamma \xi+\zeta \\
& (I-B) \eta=\alpha+\Gamma \xi+\zeta \\
& \eta=(I-B)^{-1} \alpha+\Gamma \xi+\zeta
\end{aligned}
$$

Where $\alpha$ is the intercept vector, $B$ and $\Gamma$ is the coefficient matrix and $\zeta_{=} \zeta_{1} \zeta_{2} \zeta_{\mathrm{m}}$ is the error vector in the structural equation, element $B$ presents variable influence $\eta$ and variable $\eta$ other, and elements $\Gamma$ present a direct influence of variables $\xi$ in variable $\eta$. It is assumed that $\xi$ not correlated with $\zeta$ and I - B is nonsingular. Furthermore, is the intercept vector $m \times 1, \eta$ is the endogenous latent variable $\mathrm{m} \times 1, \mathrm{~B}$ is the coefficient matrix of the endogenous latent variable $\mathrm{m} \mathrm{x} \mathrm{m}$, $\Gamma$ is the coefficient matrix of the exogenous latent variable $\mathrm{mxn}, \xi$ is the exogenous latent variable vector $\mathrm{n}$ $\mathrm{x} 1, \zeta$ structural model error vector. 


\section{Result and Discussion}

\section{Community Participation and Socio-Cultural Change in Handling Slum Settlement}

The slum settlement that has developed in Makassar City is influenced by three main factors, namely (i) community poverty, (ii) the inability of the community to find decent work, and (iii) inequality of land tenure. Land ownership and land tenure play an important role in meeting the basic needs of the community, the quality of the urban environment, housing conditions, and environmental health (Dachaga \& de Vries, 2021; Surya, et al., 2021a). Field facts that have been found indicate that the slum management program implemented so far has only focused on the physical aspect, namely improving the quality of infrastructure and its implementation is still partial. This condition illustrates that the social and economic aspects as an integral part of the slum settlement sys- tem have not been optimized for handling. The handling of slum settlements is complex and related to social, economic, environmental and infrastructure conditions, so it requires an integrated approach as an integrated urban system (Mahabir, et al., 2016; Surya, et al., 2020d). Thus, improving the quality and repair of slum areas requires synergy between the community and other development actors towards changing the quality of community life (Meredith \& MacDonald, 2017). Furthermore, community participation in handling slum settlements in Makassar City is presented in Table 1 below.

Table 1 shows community participation in handling slum settlements in Makassar City. Interpretations that can be put forward to these results include: First, community participation in relation to improving environmental quality shows differences based on

Table 1. Comparison of community participation in handling slums settlement in Makassar City

\begin{tabular}{|c|c|c|c|}
\hline \multirow[t]{2}{*}{ Parameter } & \multicolumn{3}{|l|}{ Slum Level of Settlements } \\
\hline & Heavy Slum & Moderate Slum & Light Slum \\
\hline Planning Program & $\begin{array}{l}\text { Public understanding and } \\
\text { knowledge of the planning } \\
\text { program is relatively low. }\end{array}$ & $\begin{array}{l}\text { Community participation in } \\
\text { the formulation of planning } \\
\text { programs is quite intensive } \\
\text { and is carried out through } \\
\text { surveys of their own villages } \\
\text { and mapping of programs } \\
\text { for dealing with slum } \\
\text { neighborhoods. }\end{array}$ & $\begin{array}{l}\text { The community, } \\
\text { both individually and } \\
\text { institutionally, is very } \\
\text { proactive in program } \\
\text { formulation and problem } \\
\text { mapping for the needs of } \\
\text { handling slum neighborhoods. }\end{array}$ \\
\hline Program Implementation & $\begin{array}{l}\text { Community participation in } \\
\text { program implementation is } \\
\text { very low. }\end{array}$ & $\begin{array}{l}\text { Community participation } \\
\text { in program implementation } \\
\text { is quite intensive, both } \\
\text { institutionally and } \\
\text { individually. }\end{array}$ & $\begin{array}{l}\text { The role of the community is } \\
\text { very positive in implementing } \\
\text { the program and formulating } \\
\text { achievement targets. }\end{array}$ \\
\hline $\begin{array}{l}\text { Environmental Condition } \\
\text { Evaluation }\end{array}$ & $\begin{array}{l}\text { Community participation } \\
\text { in environmental pollution } \\
\text { control is very low. }\end{array}$ & $\begin{array}{l}\text { The role of the community is } \\
\text { quite good in the process of } \\
\text { evaluating and handling the } \\
\text { needs of the slum settlement } \\
\text { environment. }\end{array}$ & $\begin{array}{l}\text { The community is directly } \\
\text { involved in solving } \\
\text { environmental problems in } \\
\text { which they live. }\end{array}$ \\
\hline Benefit Value & $\begin{array}{l}\text { Public awareness of the } \\
\text { maintenance of development } \\
\text { results is very low. }\end{array}$ & $\begin{array}{l}\text { Community involvement } \\
\text { is very good regarding } \\
\text { the maintenance of the } \\
\text { infrastructure that has been } \\
\text { built. }\end{array}$ & $\begin{array}{l}\text { Community involvement and } \\
\text { responsibility in maintaining } \\
\text { the results of program } \\
\text { implementation is very } \\
\text { positive. }\end{array}$ \\
\hline Community Contribution & $\begin{array}{l}\text { Community contributions in } \\
\text { the form of energy, ideas, and } \\
\text { materials are very low. }\end{array}$ & $\begin{array}{l}\text { Community involvement } \\
\text { in giving ideas and ideas for } \\
\text { environmental management } \\
\text { is quite positive. }\end{array}$ & $\begin{array}{l}\text { The contribution of the } \\
\text { community in terms of } \\
\text { manpower, materials, } \\
\text { and ideas for handling the } \\
\text { environment is very positive. }\end{array}$ \\
\hline Institutional Role & $\begin{array}{l}\text { Institutional participation } \\
\text { does not play a role due to } \\
\text { limited understanding of the } \\
\text { program being implemented. }\end{array}$ & $\begin{array}{l}\text { The role of the institution is } \\
\text { very active in organizing the } \\
\text { community in handling the } \\
\text { settlement environment. }\end{array}$ & $\begin{array}{l}\text { Institutional participation } \\
\text { in dealing with and solving } \\
\text { environmental problems is } \\
\text { very positive. }\end{array}$ \\
\hline
\end{tabular}

Source: Primary data and analysis results 
the level of slums in the settlements. These differences are closely related to knowledge, culture, and community response to program implementation. The results of the Focus Group Discussion (FGD) illustrate that community participation has a direct relationship with socio-cultural conditions. Thus, the program for handling slum settlements, which are dominated by poor people with poor environmental conditions, will require facilitation and assistance based on community empowerment and participation by considering socio-cultural conditions towards improving environmental quality and community welfare in a sustainable manner (Surya, 2015a; Hasanawi, et al., 2019; Surya, et al., 2021b). Furthermore, the factors that influence community participation in the implementation of the slum settlement program are (i) internal factors, namely age, education level, type of work, income level and length of stay, and (ii) external factors, namely communication and leadership in this case the function and role of institutions that are less than optimal in socialization activities have an impact on the weak level of trust and community participation in program implementation. Furthermore, settlements in the category of heavy slums which are dominated by fishing communities are strongly influenced by the work orientation of the community as fishermen who depend on water resources, in the sense that the culture of the fishing community is closely related to the socio-economic relations that are built, namely the patron-client relationship. This means that the dominant pattern of community life still depends on business owners with positive associations on community participation in the implementation of slum settlement programs implemented by the government. Furthermore, settlements with heavy slum categories which are dominantly inhabited by fishing communities are strongly influenced by the work orientation of the community as fishermen who depend on water resources for their lives, in the sense that the culture of the fishing community is closely related to the social relations that are built, namely the patron-client relationship. Meanwhile, settlements with medium and low slum categories are dominated by urban industrial workers, in the sense that the community is not bound by time, so it is very easy to move both individually and institutionally. The main characteristics usually associated with informal settlements are irregular land ownership, self-built housing, low levels of infrastructure and lowincome population (UN-Habitat, 2003). Furthermore, socio-cultural conditions and job characteristics greatly influence community participation and response to the implementation of the slum management program (Surya, 2015b; Mohanty, 2020).

Second, the understanding and level of knowledge that is quite low on the benefits of the program is closely related to the factors of poverty, leadership, and the social structure of the community. This means that community participation in the implementation of the program is closely related to the value of the benefits obtained economically, so that the community considers that the slum settlement program is not their responsibility either individually or institutionally. The poor who live in slum settlements will take the initiative if their needs are met (Lombard, 2014). Thus, the improvement of slum settlements will work well if the social networks of residents and community cohesiveness remain intact and the implementation of government programs is more towards improving their standard of living (Rashid, 2009; Surya, et al., 2018). Third, the slum settlement program that has been implemented by the government is more dominant in improving the quality of infrastructure. That is, programs that are economic in nature and solving social problems that are less touched as a unified system that is integrated with people's lives cause community participation in handling slum settlements to be less than optimal. Thus, it can be concluded that the slum settlement program that does not touch the basic needs of the community socially and economically causes weak community participation in the implementation of the slum settlement program in Makassar City. This means that an integrated slum management system is needed through a strategic program that is carried out comprehensively and in an integrated manner towards solving economic, social problems and improving environmental quality (Archer, 2009).

The handling of slum settlements carried out by the government in Makassar City in addition to encouraging increased community participation also contributes to socio-cultural changes. This condition is characterized by changes in social structures and social systems. Furthermore, changes in community culture are marked by changes in behavior and community responses to support environmental quality improvement. This means that the slum settlement program implemented through infrastructure intervention and the fulfillment of socio-economic facilities has changed the attitudes and behavior of the community, both individually and institutionally. This condition is marked by an increase in the aesthetics of the residential environment and public awareness to live clean in their activities, as well as an understanding of their rights and obligations towards their residential environment. This means that government intervention through slum settlement programs is one of the causes of socio-cultural changes towards improving the quality of people's lives. Furthermore, the facts found in the field indicate that the formation of community institutions is closely related to the system of values and norms that are known, 
understood, respected, and obeyed by all community members living in slum settlements. This means that customs and habits have been institutionalized in such a way and are believed by the community as the basis and reference for action and if they are not implemented, something bad will happen to members of the community or the whole community. This tradition is especially developed in communities living in coastal and river areas with the belief that values, and norms are the basis for avoiding natural disasters and dangers that will threaten people's lives.

The results of interviews conducted illustrate that the function of community institutions in slum settlements in Makassar City plays an important role in building trust in strategic programs implemented by the government. If it is based on the type of institution that develops, it illustrates that the existence of these institutions plays a role in regulating community behavior in relation to the situation and conditions of people living in slums. Community trust, social capital, and social ties between residents, play an important role in overcoming social problems that develop in the dynamics of the people who inhabit slum areas (Obaitor, et al., 2021). The basis and parameters for assessing the function and role of community institutions in slum settlements in Makassar City are: (1) Crescive institutions, namely institutions that accidentally grow from the customs and traditions of the community; (2) From the point of view of acceptance, it is categorized into social sanctioned institutions which are accepted by the whole community; and (3) The value system accepted by the community becomes the basic institution. Furthermore, there are two categories of socio-economic life that develop in the dynamics of the development of slum settlements in Makassar City: First, the subsistence economy, this system is dominantly adopted by fishing communities and people whose main activity orientation is as port workers. The characteristics inherent in the social relations that are built are kinship, mutual, cooperation and brotherly relations. This condition is shown in the pattern of social interaction that is close in nature as a community unit. That is, in people's lives tend to be bound by traditions that are hereditary in nature. Second, the commercial economy, this system is dominant in people who occupy slum areas with the category of light slums. The orientation of the community's economic activities is dominant in the service sector, construction workers, and small and medium enterprises. The inherent characteristics and social relations that are built are relatively loose and more towards the lifestyle of urban communities. The economic system of the people in slum areas with categories of heavy slums and medium slums is at the subsistence economic level and is dominated by the urban poor. This means that the pattern of economic activity and the level of community income are classified as very low for the two typologies of slum settlements, in the sense that the income earned is only used to meet the needs of daily life and has difficulty meeting proper housing facilities and the condition of settlement infrastructure that does not meet minimum service standards.

The facts found in the field show that the activities of the people who still rely on their lives as fishermen are not only because of the need for a living, but also because of the historical ties that are still preserved. In general, three patterns of life can be explained, namely (i) appearing on the surface in an atmosphere of socio-economic activities conditioned by the life of fishermen by relying on nature as a source of life, (ii) the dominant form of settlement on stilt houses, (iii) the basis of life that becomes the glue social relations are the environment of traditions, religious beliefs, and socio-cultural ties. Furthermore, the characteristics of slum settlements that develop in Makassar City which can be explained include: (1) Slum settlements that develop in commercial activities are dominated by immigrants with ethnic diversity. The relationship between ethnic and community that is built is more towards economic relations and the main occupations of the community are developed, namely the urban informal economy, construction workers, and casual workers. (2) Slum settlements in industrial activities are dominated by immigrants as industrial workers and occupy residential facilities (rental flats) prepared by the government. The social interactions that are built are reciprocal and mutually beneficial. (3) Slum settlements located in the port area. These settlements are inhabited by migrants and local communities and the provision of community housing facilities is built independently with illegal land status. The main occupation orientation of the community is port workers and casual workers. The social relations that are built are reciprocal. The main problems that are often faced by the community are social conflicts, urban flooding, environmental pollution, and the condition of residential buildings that are unfit for habitation. (4) Slum settlements located on riverbanks and coastal areas that occupy illegal land. The main occupations of the community are fishermen, port workers, and odd jobs. The social relations that are built are symbiotic mutualism and (5) Slum settlements that develop in suburban areas are dominated by local communities and immigrants. The orientation of the community's main activities are building construction workers, day laborers, garbage scavengers, and the urban informal sector. Furthermore, the socio-cultural characteristics of the community before and after experiencing changes are presented in Figure 2. 

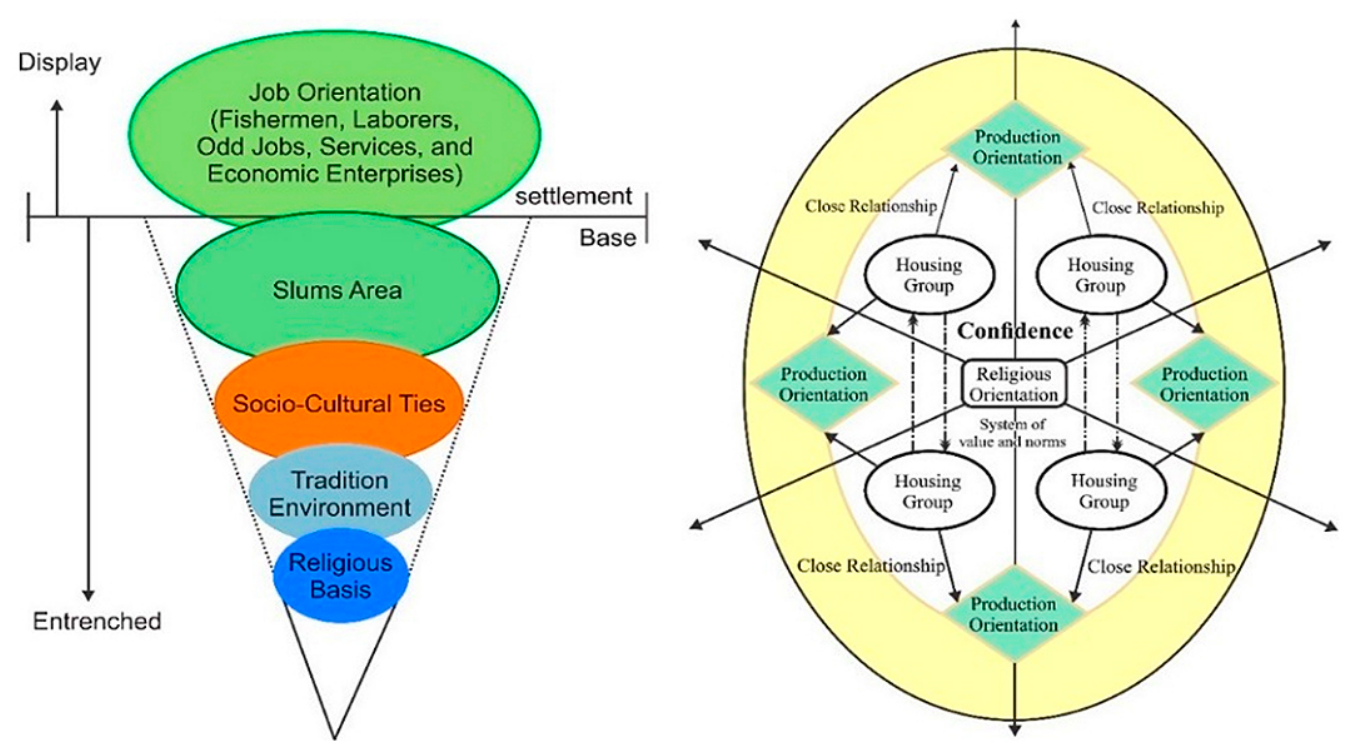

Figure 2. The display pattern of the socio-cultural life of the community in slum settlements in Makassar City.

(A) Before the change; (B) After the change

Figure 2A shows the appearance of the socio-cultural life of the community before undergoing changes. Interpretations that can be put forward to this condition, among others: (1) The adhesive element of community kinship relations in slum settlements in Makassar City is a belief system (religion) that is still attached and feels its ability is limited in dealing with its environmental situation; (2) Belief in the existence of a supreme ruler of the universe system is considered to have a direct connection with the pattern of people's lives (myths against natural rulers). These beliefs are then formulated in controlling people's daily lives related to a series of behaviors and procedures related to the highest authority, which if violated by the community they believe will bring disaster to their lives. These results confirm that the values and norms held by the community are still traditional. Durkheim, (1986), mentions that religion arises from social sentiment. Religious feelings or emotions arise in the human mind as a result, of social sentiments. The form of social sentiment arises as a result, of feelings in every member of society who are influenced by collective assumptions. This means that the community's response, both individually and collectively, has fostered a belief in something that is sacred and is believed by the community to have a negative impact on their daily lives if it is not implemented. Thus, it can be concluded that the emergence of culture which is interpreted in tradition is basically not independent but is related to the orientation of people's livelihoods as a unified system.

The facts found in the field illustrate that the pattern of community activity that develops is related to settlement grouping and production orientation in slum settlements in Makassar City which can be explained, among others: (1) The grouping of settlements that are oriented towards informal economic activities through the intervention of built infrastructure contributes to the increase in community welfare efforts by $34.82 \%$. This condition occurs due to the ease of accessibility, mobility, and access to consumers. (2) The grouping of settlements that are oriented towards industrial activities through the intervention of settlement infrastructure development contributes to the ease of community movement patterns towards an increase in welfare by $22.32 \%$. (3) The grouping of settlements that are oriented towards activities in the service sector through the intervention of infrastructure development support contributes to the improvement of community welfare by $23.76 \%$. (4) The grouping of settlements that are oriented towards productive economic enterprises (small and medium enterprises) through infrastructure intervention contributes to the increase in community welfare by $19.1 \%$. These results illustrate that the grouping of settlements based on the orientation of production activities developed by the community through infrastructure development interventions has a significant effect on the pattern of life and the level of community welfare and its effect on reducing the level of slum settlements in Makassar City. Furthermore, the social system and community behavior are closely related to the level of community participation in handling slum settlements. This means that the handling of slums requires comprehensive efforts, both physically, economically, and socioculturally. Thus, changes in behavior, attitudes, motivation, responsibility, and community participation will encourage the successful implementation of handling slum settlements in Makassar City. Restructuring the handling of slums, 
which is followed by socio-cultural changes and integrated with the handling of infrastructure, will encourage an increase in the welfare of the community (Jones, 2017; Purwanto, et al., 2017). Thus, changes in behavior, attitudes, and community responsibilities play an important role in the sustainability of the handling of slum settlements (Teferi, \& Newman, 2017).

Figure $2 \mathrm{~B}$, shows the mixing of community cultures in slum settlements in Makassar City. Interpretations that can be put forward to the results include: First, the entry of migrants triggered by the development of new functions and other economic activities. This condition directly has an impact on the sociocultural changes of the community, in terms of the traditions that have been implemented so far have experienced a declining appreciation. Population movements that occur directly condition the relationship of reciprocal communication between the existing ethnic groups. As a result, individuals in community groups are faced with cultural elements of the immigrant population who enter infiltratively. Furthermore, the interaction between individuals of different ethnicities causes each, individual to experience a social process (the process of interaction and adaptation). Second, the social contacts that occur between local communities and migrant residents in slum settlements are more towards the relationship between individuals in groups based on the principle of meeting economic needs. This condition illustrates that there are social relations that are built more towards mutually beneficial economic relations (symbiotic mutualism).
Third, the presence of migrants in slum areas in Makassar City begins with the presence of those who do not have houses and the local community responds by providing accommodation facilities (contract houses). This fact illustrates the articulation process that occurs between local communities and migrants with the principle of mutual benefit (immigrants get a place to live and the local community gets additional income from the cost of the rental contract). The entry of immigrants does not necessarily change the pattern of socio-cultural activities of the local community, what happens is that there is an attitude of mutual acceptance between one another and fosters togetherness between them and fosters mutual trust which in turn creates close relationships between individuals in community groups. The entry of migrants into community settlements causes socio-cultural changes through the process of acculturation and assimilation which is characterized by the spread of different cultural elements. This means that the existence of certain ethnicities is a motivation for people to improve their common welfare and work as laborers, craftsmen, and formal workers in urban commercial and industrial activities. Thus, it can be concluded that the socio-cultural conditions of the community will always experience changes when the environmental situation also changes. In turn, changes in the external environment in the community and psychological factors, social and economic togetherness will create integration between residents as a unified social system in the community (Negru, et al., 2016). Furthermore, community participation in han-

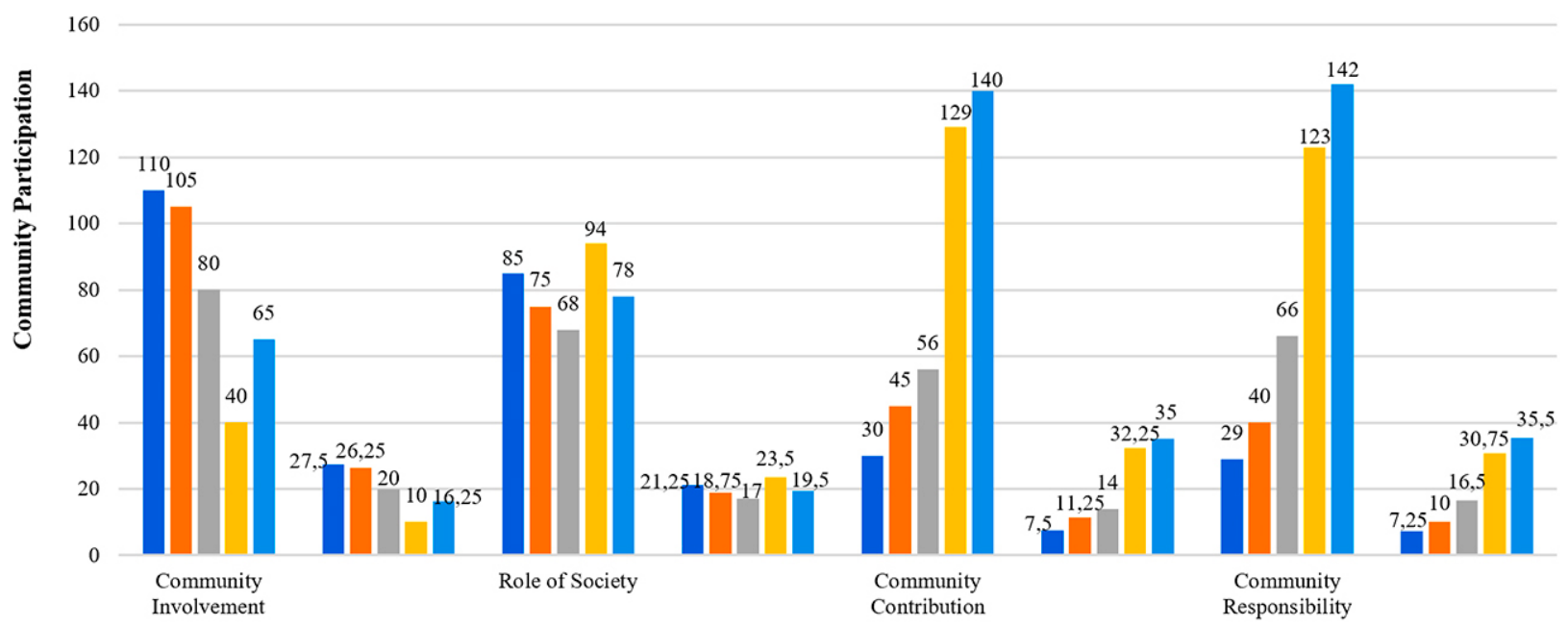

Handling Slum Settlement Program

Figure 3. Community participation in the slum settlement program 
dling slum settlements in Makassar City is presented in Figure 3.

Figure 3 shows community participation in the slum settlement program in Makassar City. Interpretations that can be put forward to the results, among others: First, community involvement in the slum settlement management program illustrates $53.75 \%$ in the supportive category, $20 \%$ in the moderately supportive category, and $26.25 \%$ in the not supportive category. This figure confirms that community involvement in the handling of slums is quite positive in relation to the implementation of physical programs in the field as workers. Second, the role of the community in the slum settlement program illustrates $40 \%$ in the supportive category, $17 \%$ in the moderately supportive category, and $43 \%$ in the not supportive category. This figure confirms that the community will, play a role in handling slum settlements, if the program implemented is in direct contact with the needs of the community. Third, the community's contribution to the slum settlement program shows $18.75 \%$ in the supportive category, $14 \%$ in the moderately supportive category, and $67.25 \%$ in the not supportive category. This figure confirms that the weak role of the community in implementing the program is more due to lack of understanding and inadequate knowledge, so that people tend to accept the programs implemented by the government.

Fourth, the community's responsibility for the results of program implementation is $17.25 \%$ in the supportive category, $16.5 \%$ in the moderately supportive category, and $66.25 \%$ in the not supportive category. This figure confirms that community responsibility for the results of program implementation in relation to maintenance and utilization tends to be low on development outcomes. These four things illustrate that community participation which tends to be low is more influenced by lack of understanding and knowledge of program implementation. This means that community participation tends to be low due to the role of the community who were not involved in the formulation of the program from the start. Local knowledge and public participation are an important part of sustainable development in terms of preventing conflicts of interest and ensuring that community interests are met (Wah Ho, 2020; Choi et al., 2021). Furthermore, the community's response to the quality and availability of slum infrastructure in Makassar City is presented in Figure 4.

Figure 4 shows the quality and availability of slum infrastructure in Makassar City. Interpretations that can be put forward to the results include: First, the ease of accessibility shows that $41.75 \%$ is categorized as supportive, $17 \%$ is categorized as moderately supportive, and $41.25 \%$ is categorized as not supportive. This figure confirms that improving the quality of infrastructure contributes to the ease of population mobility to reach socio-economic activities. Second, the quality of the slum road network illustrates $43.5 \%$ in the supportive category, $17 \%$ in the moderately supportive category, and $39.5 \%$ in the not supportive category. This figure confirms that the road network currently built with paving block surface conditions and concrete rebates provides benefits for the socio-economic activities of the community in addition to increasing the aesthetic value of the slum neighborhood. Third, the fulfillment of clean water needs shows $18.75 \%$ in the supportive category, $11.5 \%$ in the moderately supportive category, and $69.75 \%$ in the not supportive category. This figure confirms that the com-

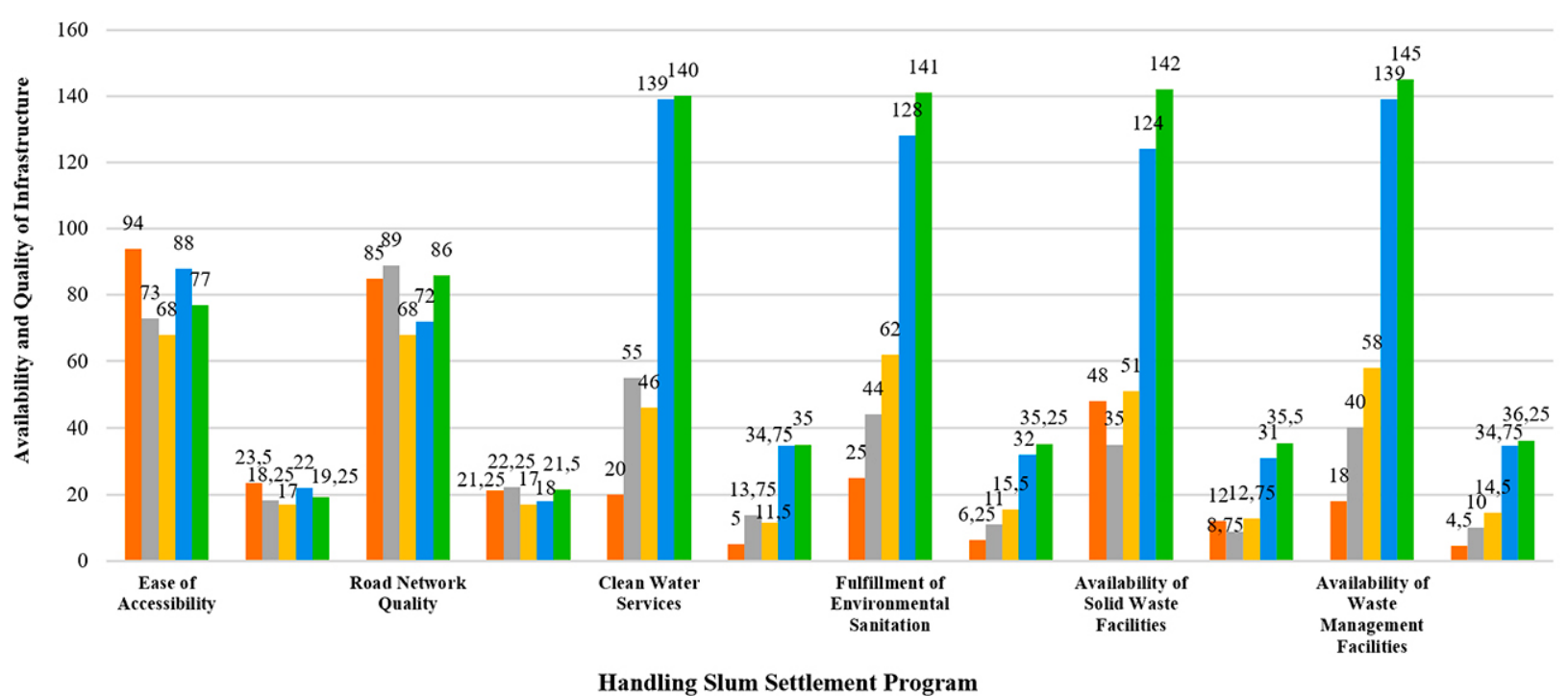

घery Supportive $\quad$ Supportive $\quad$ Sufficiently Supportive $\quad$ Less Supportive

Figure 4. Quality and availability of slum settlement infrastructure 
munity's clean water service system as a basic need has not been met both in terms of the flowed discharge and from the existing connection system, as a result, people who are located, in slum settlements predominantly use deep groundwater wells and river water to fulfill their needs for bathing, washing, and the outhouse. Water, sanitation, and hygiene (WaSH) are prerequisite to human health and development, since clean water is essential for human's daily living especially for drinking water (Surya, 2015c).

Fourth, the fulfillment of environmental sanitation obtained an overview of $17.25 \%$ in the supportive category, $15.5 \%$ in the moderately supportive category, and $67.25 \%$ in the not supportive category. This figure confirms that the community's environmental sanitation system in slum settlements is very limited, as a result, people use rivers as a place to dispose of their feces, and the impact on the health of the settlement environment. Fifth, the availability of solid waste facilities illustrates that $20.75 \%$ in the supportive category, $12.75 \%$ in the moderately supportive category, $66.5 \%$ in the not supportive category. This figure confirms that limited waste facilities in slum areas cause people to use drainage channels, rivers, and the local environment as waste disposal media and a small number of people handle their household waste in the conventional way, namely burning and dumping in the ground. These conditions then have an impact on the quality of the living environment, disruption of water flow in drainage channels and pollution of river water quality. Sixth, household waste management obtained a picture of $14.5 \%$ in the supportive category, $14.5 \%$ in the moderately supportive category, and $71 \%$ in the not supportive category. This figure confirms that the handling of household waste in slum areas has not been handled properly. This means that household waste is directly channeled to the local environment and channeled directly to water bodies, thus having an impact on environmental pollution, and decreasing river water quality. The six factors whose values are related to slum settlement infrastructure illustrate that only road infrastructure is fulfilled, while the other four factors, namely clean water services, environmental sanitation, solid waste, and household waste in relation to the handling of slum settlements in Makassar City have not been effective in implementation and does not provide benefits to improving the quality of the settlement and community environment. Communities in informal settlements accept the risks posed by garbage, poor sanitation, wastewater, and lack of clean water supplies and their impact on the health of the community and the quality of the settlement environment (Olafsdóttir, 2021; Irda Sari et al., 2018). Furthermore, the influence of community participation, improving the quality of infrastructure, improving the quality of the environment, and changing the socio-cultural community on the sustainability of Makassar City development is presented in Table 2 below.

The results of Table 2 which can be explained include: (1) community participation has a positive effect on the sustainability of urban development, (2) the quality of infrastructure has a positive effect on the sustainability of urban development, (3) the environmental quality index has a positive effect on the sustainability of urban development, and (4) socio-cultural changes have a positive effect on the sustainability of urban development. Thus, it can be con-

Table 2. Summary of test results for the significance of multiple regression coefficients

\begin{tabular}{|c|c|c|c|c|c|c|}
\hline \multirow{2}{*}{\multicolumn{3}{|c|}{ Correlation }} & Coefficient & Error & \multirow{2}{*}{ t-count } & \multirow{2}{*}{ t-table } \\
\hline & & & $\beta$ & Sbi & & \\
\hline \multicolumn{3}{|c|}{$\begin{array}{l}\text { Community participation towards sustainability of } \\
\left.\text { city development (ry } x_{1}\right)\end{array}$} & 0.182 & 0.056 & 2.893 & 1.94 \\
\hline \multicolumn{3}{|c|}{$\begin{array}{l}\text { Improving the quality of infrastructure towards } \\
\text { sustainability of city development (ryx2) }\end{array}$} & 0.139 & 0.054 & 2.856 & 1.94 \\
\hline \multicolumn{3}{|c|}{$\begin{array}{l}\text { Improving the quality of the environment towards } \\
\text { sustainability of city development }\left(r x_{3}\right)\end{array}$} & 0.408 & 0.093 & 4.185 & 1.94 \\
\hline \multicolumn{3}{|c|}{$\begin{array}{l}\text { Sosio-culture change towards sustainability of city } \\
\text { development }\left(\mathrm{ryx}_{4}\right)\end{array}$} & 0.406 & 0.097 & 4.273 & 1.94 \\
\hline Source variant & $\begin{array}{l}\text { Sum of squares } \\
\text { (JK) }\end{array}$ & $\begin{array}{l}\text { Free Degrees } \\
\text { (db) }\end{array}$ & \multicolumn{2}{|c|}{$\begin{array}{l}\text { Average of the sum of the } \\
\text { squares (RJK) }\end{array}$} & F-count & $\begin{array}{l}\text { F-table } \\
\alpha=0.05\end{array}$ \\
\hline $\begin{array}{l}\text { Regression } \\
\text { Residue }\end{array}$ & $\begin{array}{l}21,648 \\
0,548\end{array}$ & $\begin{array}{l}4 \\
8\end{array}$ & $\begin{array}{l}8,556 \\
0.084\end{array}$ & & 89,815 & 7.82 \\
\hline Total & 21,648 & 12 & - & & - & - \\
\hline $\mathrm{R}$ & $\mathrm{R} 2$ & $\mathrm{db} 1$ & $\mathrm{db} 2$ & & F-count & F-table \\
\hline 0.878 & 0.771 & 4 & 8 & & 89,815 & 7.82 \\
\hline
\end{tabular}

Source: Analysis results 
cluded that community participation, infrastructure quality, environmental quality index, and socio-cultural changes of the community simultaneously affect the sustainability of Makassar City development with a coefficient of determination of $77.1 \%$. These results confirm that community participation, improving the quality of infrastructure, improving the quality of the environment, and changing the socio-cultural community that are carried out in an integrated and comprehensive manner will have an impact on the success of handling slum settlements towards sustainable development in Makassar City. Thus, it is very important to integrate a planning system followed by a strategic program from the government in order, to support the handling of informal settlements and improve the quality of the urban environment (Ferronato, \& Torretta, 2019; Surya, et al., 2020e; Akmal, \& Jamil, 2021). Thus, the settlement of slum settlements in Makassar City in the future will require periodic monitoring and evaluation to ensure the accuracy of the quality and targets of activities through the support of active community participation. This means that the acceleration of the handling of slum settlements is very important to be integrated with strengthening the capacity of the government and the community which is carried out jointly for each stage of activity, including encouraging changes in community behavior and public awareness to be responsible for the utilization and maintenance of basic infrastructure facilities for settlements. Furthermore, the results of the SEM analysis are presented in Figure 5.

Figure 5 shows the estimation model for the handling of slum settlements, community participation, and socio-cultural changes in the community towards the sustainable development of Makassar City. Interpretations that can be put forward to the model include: First, the construct (latent variable) of the slum settlement sector, community participation, and socio-cultural changes have a positive effect on the sustainability of Makassar City development. The results of the chi-squares test show a value of 123.520 with a probability of $\mathrm{p}=0.132>0.05, \mathrm{df}=94$, gfi $=$ 0.871 , cfi $=0.776$. This figure confirms that the model built is categorized as a fit model. Second, the total influence of community participation on the variable handling of slum settlements is 0.62 .41 or $62.41 \%$, community participation on endogenous variables of socio-cultural change is 0.4761 or $47.61 \%$, and community participation on endogenous variables of urban development sustainability is 0.4624 or 46.24 .

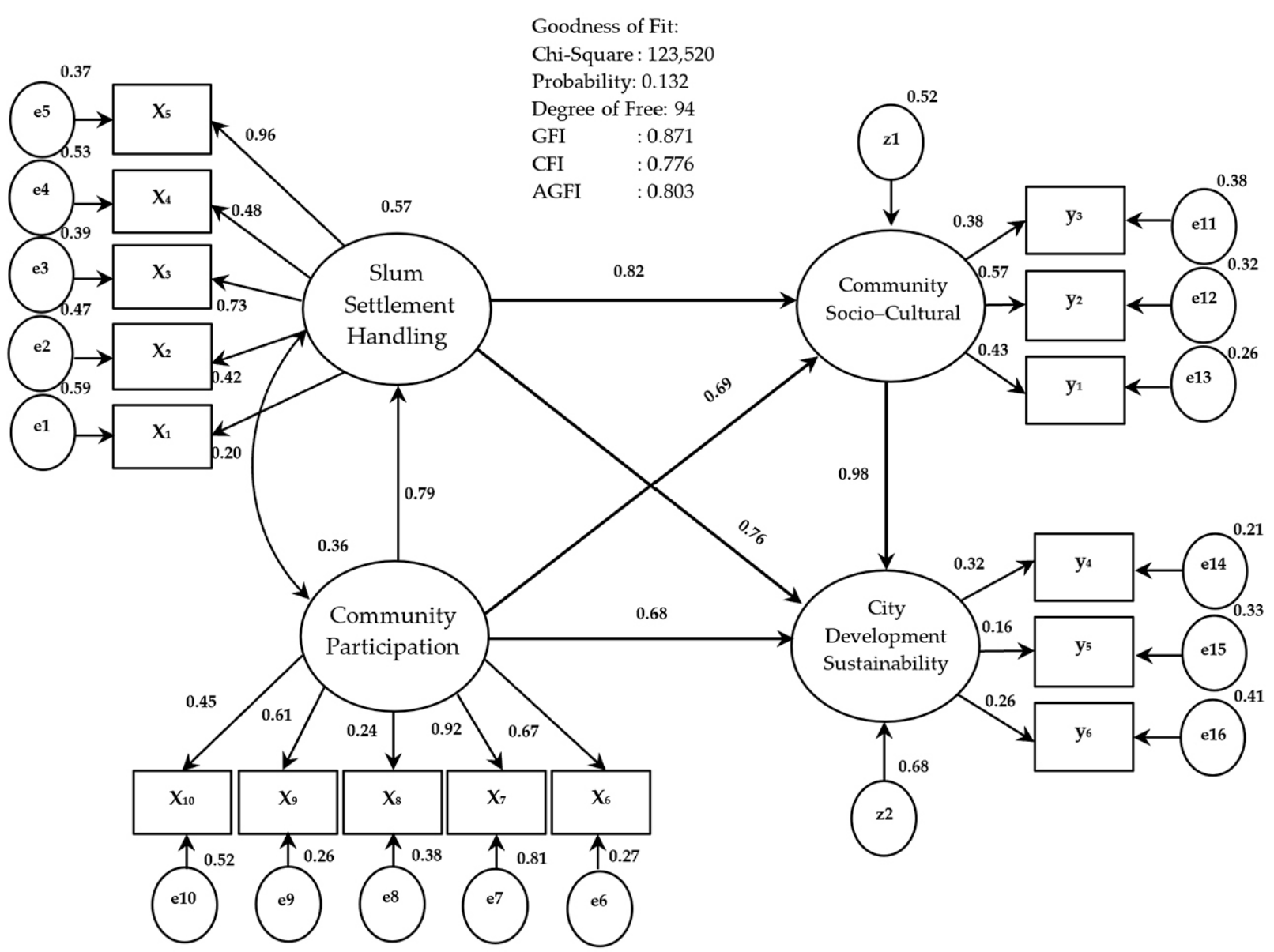

Figure 5. The estimation model for the handling of slum settlements, community participation, and socio-cultural changes in the community towards the sustainable development of Makassar City 
Third, the total influence of the construction of slum settlements on the endogenous variables of sociocultural change is 0.6724 or $67.24 \%$, the handling of slums on the endogenous variables of urban development sustainability is 0.5776 or $57.76 \%$. The fourth effect of the total endogenous variables of socio-cultural changes on the endogenous variables of urban development sustainability is 0.9604 or $96.04 \%$.

The orientation of the sustainable development of Makassar City in relation to the handling of slum settlements in the future is focused on four categories, including: (1) Handling of slum settlement infrastructure is focused on improving the quality of environmental roads, environmental drainage, clean water services, waste management and the provision of environmental sanitation and hygiene provision of waste facilities; (2) Community participation is focused on several things, namely increasing community roles, community involvement in program formulation, contribution of community thoughts and ideas, involvement in program implementation, and community responsibility for maintaining program outcomes; (3) The socio-cultural changes of the community in dealing with slum settlements are focused on several things, namely changing attitudes, increasing knowledge, and changing people's behavior, in the sense of creating an environmentally conscious culture; and (4) the sustainability of urban development is focused on three main things, namely environmental sustainability, economic sustainability, and social sustainability. The implementation of the strategic program in addition to having an impact on improving the quality of slum settlements, creating equitable distribution of development, and improving community welfare towards the creation of social cohesion, community productivity, and harmonization of people's lives in Makassar City. Thus, it is necessary to evaluate the slum settlement program that has been implemented in Makassar City.

\section{Slum Settlement Hadling in Makassar City}

Participatory processes refer to processes that actively involve the role of the government, the private sector, and community institutions which are based on traditional values and optimize the use of community social capital to support program implementation (Nassar \& Elsayed, 2018; Surya et al., 2021b). Furthermore, in order, to foster the motivation of the poor to participate, policy support is needed that refers to the aspirations of the community and is carried out through a process of deliberation and consensus based on mapping the problems of the slum settlement environment which is carried out by the community independently and mutually agreed by both individuals and institutions. Furthermore, the handling of slum settlements in Makassar City is aimed at building public awareness of their rights, obligations, and responsibilities towards the environmental conditions in which they live. Thus, the solution to achieve the target of handling slum settlements in the future in Makassar City is very important to involve the role of the community which is integrated with strategic programs from the government optimally in order, to achieve sustainable development goals (SDGs), namely (i) poverty reduction, (ii) ease of obtaining decent work, (iii) reduction of socio-economic inequalities, and (iv) sustainability of slum settlement management towards sustainable city development.

Social-culture changes in the community related to the handling of slum settlements in Makassar City will require strategic steps, including: (1) Changes in people's attitudes in responding to changes in the environmental situation. This means that changes in people's attitudes are needed as a form of adaptation in the form of real community actions to maintain and maintain the environmental conditions in which they live; (2) Increasing public knowledge, through socialization efforts that are carried out continuously and carried out based on initiatives from the community, both individually and in the form of institutions; (3) Changes in people's behavior to handle and control environmental pollution towards the fulfillment of healthy and sustainable environmental standards. These three things require consistent efforts and policy support from the Makassar City government.

\section{Sustainability of Makassar City Development}

The handling of slum settlements is related to the sustainability of Makassar City development, in its implementation, it is oriented to three basic principles, namely: (1) The principle of equality between generations as the basic principle of sustainable development oriented to the completion of the handling of slums; (2) The principle of justice in the sense of ensuring economic access and distribution of natural resources to overcome poverty problems that are integrated with improving the quality of the slum settlement environment; and (3) the principle of responsibility in the sense of ensuring a minimal geographic shift in environmental impact through compensatory measures. That is, in the context of urban development and the fulfillment of housing needs for the urban poor, it is developed towards improving environmental quality and is inclusive. Furthermore, the city development policy in the form of a spatial plan functions as an instrument of regulation, implementation, and control which is carried out through several basic principles, including: (1) Responsibility to implement and implement sustainable urban and settlement development; (2) Right to carry out urban development policies and 


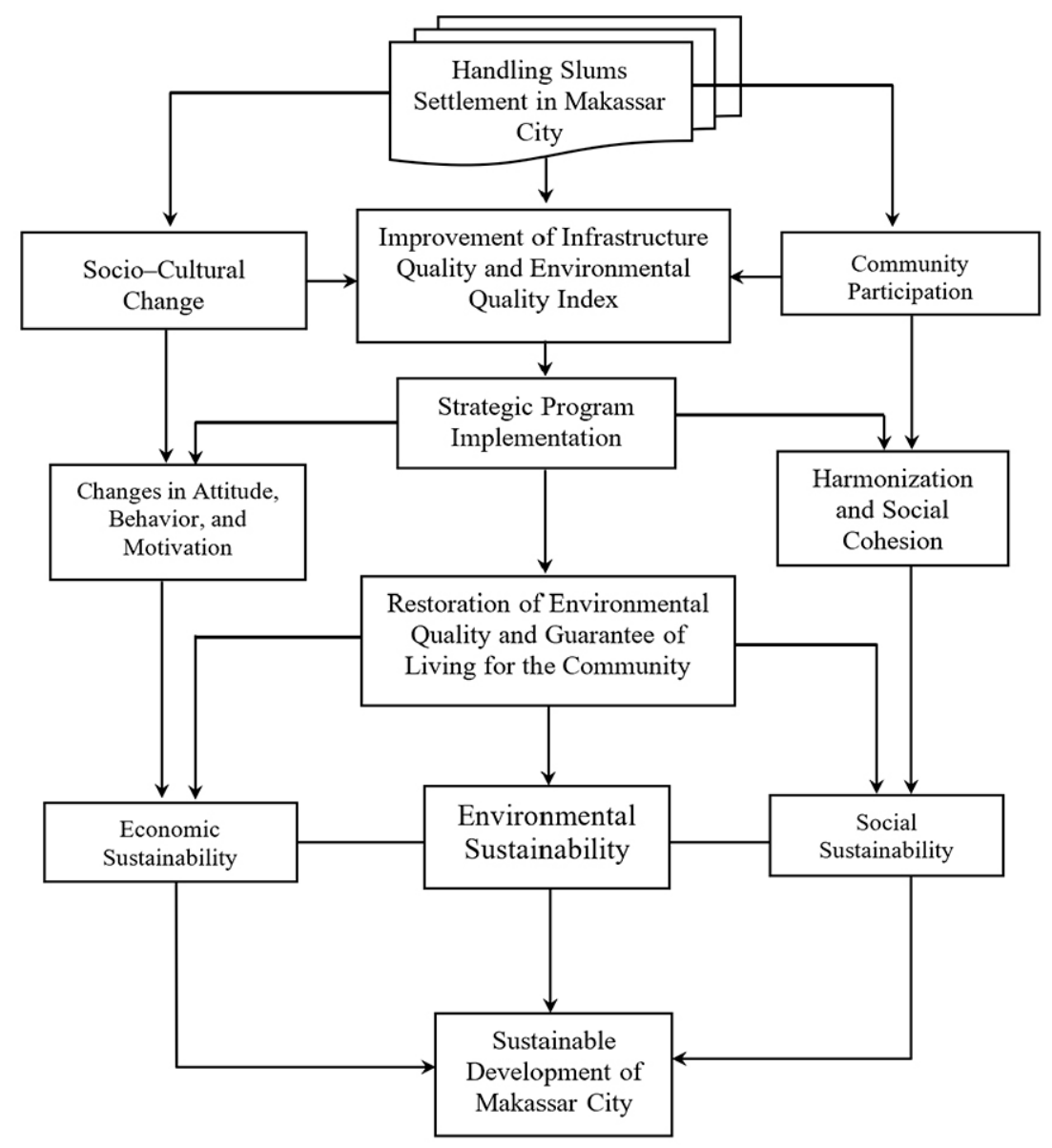

Figure 6. Handling of slum settlements and sustainable development of Makassar City

programs with reference to the broad public interest; (3) Risk, in the sense that city development decision making is oriented towards environmental, economic and social sustainability; (4) Revenue, in the sense that the implementation of city development policies and programs refers to the strategic program and is in direct contact with the value of the benefits that will be received by the community; and (5) Relations, in the sense of building cross-sectoral development coordination in order to realize sustainable urban development. The Makassar City development sustainability scheme is presented in Figure 6 below.

\section{Conclusion}

Community participation in handling slum areas is closely related to socio-cultural conditions and community work orientation. The level of understanding and knowledge that is quite low about program implementation is positively related to poverty, leadership, and community social structures. Furthermore, the community will participate in the implementation of the program if the value of economic benefits is obtained. Programs that do not touch the basic needs of the community socially and economically lead to weak community participation. Community-based development programs will encourage a sense of ownership of the program voluntarily and are responsible for the results of program implementation. Thus, to motivate the poor who live in settlements to par- ticipate, it is necessary to absorb aspirations through a process of deliberation and consensus and refer to the results of mapping the problems of the slum environment carried out by the community independently and mutually agreed by both individuals and institutions.

The orientation of the sustainable development of Makassar City in relation to the handling of slum settlements in the future is focused on four categories, including: (1) Handling of slum settlement infrastructure is focused on improving the quality of environmental roads, environmental drainage, clean water services, waste management and the provision of environmental sanitation and hygiene provision of waste facilities; (2) Community participation is fo- 
cused on several things, namely increasing community roles, community involvement in program formulation, contribution of community thoughts and ideas, involvement in program implementation, and community responsibility for maintaining program outcomes; (3) The socio-cultural changes of the community in dealing with slum settlements are focused on several things, namely changing attitudes, increasing knowledge, and changing people's behavior, in the sense of creating an environmentally conscious culture; and (4) the sustainability of urban development is focused on three main things, namely environmental sustainability, economic sustainability, and social sustainability.

\section{Acknowledgments}

We are grateful for the participation of stakeholders in contributing ideas in carrying out this research. Thanks to the Ministry of Education, Culture, Research, and Technology of the Republic of Indonesia and the Bosowa Foundation for their financial support and assistance in carrying out this research. This research was carried out with the approval of the Institute for Research and Community Service (LPPM, University of Bosowa Makassar) through the Cooperation Contract Number 12/LPPM/I/2021 dated January 10, 2021.

\section{References}

Archer, D. (2009). Social Capital and Participatory Slum Upgrading in Bangkok, Thailand. Department of Land Economy University of Cambridge. This dissertation is submitted for the degree of Doctor of Philosophy; https://doi.org/10.17863/ CAM.16428. London: University of Cambridge Publishing.

Akmal, T., \& Jamil, F. (2021). Testing the Role of Waste Management and Environmental Quality on Health Indicators Using Structural Equation Modeling in Pakistan. International Journal of Environmental Research and Public Health, 18(8), 4193; https://doi.org/10.3390/ijerph18084193

Biro Pusat Statistik (BPS) Kota Makassar. (2020). Kota Makassar Dalam Angka. Makassar: Penerbit BPS Kota Makassar

Choi, D.S., Sang Youn, J., Lee, I.H., Choi, B.J., \& Joon Jeon, K. 2021. Considering Condensable Particulate Matter Emissions Improves the Accuracy of Air Quality Modeling for Environmental Impact Assessment. Sustainability, 13(8), 4470; https://doi. org $/ 10.3390 /$ su13084470

Cochran, W.G. (1977). Sampling Techniques, 3rd Edition: New York, Chichester, Brisbane, Toronto, \& Singapore: John Wiley \& Sons, Ltd.

Dachaga, W., \& de Vries, W.T. (2021). Land Tenure Security and Health Nexus: A Conceptual Framework for Navigating the Connections between Land Tenure Security and Health. Land, 10(3), 257; https:// doi.org/10.3390/land10030257

Durkheim, E. (1986). Durkheim dan Pengantar Sosiologi Moralitas. Disunting oleh Tafik Abdullah dan A.C. van der Leeden: Penerbit. Yayasan Obor Indonesia.
Friesen, J., Taubenböck, H., Wurm, M., \& Pelz, P.F. (2018). The similar size of slums. Habitat International, 2018, 73, 79-88; https://doi.org/10.1016/j. habitatint.2018.02.002

Ferronato, N., \& Torretta, V. (2019). Waste Mismanagement in Developing Countries: A Review of Global Issues. International Journal of Environmental Research and Public Health, 16(6), 1060; https://doi.org/10.3390/ijerph16061060

Gong, J., Chen, W., Liu, Y., \& Wang, J. (2014). The intensity changes of urban development land: Implications for the city master plan of Guangzhou, China. Land Use Policy, 40, 91-100; https://doi. org/10.1016/j.landusepol.2013.05.001

Hasanawi, A., Masturi, H., \& Hasanawi, A. (2019). Improvement of Community Governance to Support Slum Upgrading Programs in Indonesia. The Indonesian Journal of Development Planning, III (3),347-358; https://doi.org/10.36574/jpp.v3i3.88

Irwanto. (2006). Focus Group Discussion: Sebuah Pengantar Praktis. Jakarta: Penerbit. Yayasan Obor Indonesia.

Irda Sari, S.Y., Sunjaya, D.K., Furusawa, H.S., Watanabe, C., \& Raksanagara, A.S. (2018). Water Sources Quality in Urban Slum Settlement along the Contaminated River Basin in Indonesia: Application of Quantitative Microbial Risk Assessment. Journal of Environmental and Public Health, 3806537, 7, 1-8; https://doi.org/10.1155/2018/3806537

Jones, P. (2017). Formalizing the Informal: Understanding the Position of Informal Settlements and Slums in Sustainable Urbanization Policies and Strategies in Bandung, Indonesia. Sustainability, 9(8), 1436; https://doi.org/10.3390/su9081436 
Lombard, M. (2014). Constructing ordinary places: Place-making in urban informal settlements in Mexico. Progress in Planning, 94, 1-53; https://doi. org/10.1016/j.progress.2013.05.003

Mahabir, R., Crooks, A., Croitoru, A., \& Agouris, P. (2016). The study of slums as social and physical constructs: challenges and emerging research opportunities. Regional Studies, Regional Science, 3(1),399-419; https://doi.org/10.1080/2168137 $\underline{6.2016 .1229130}$

Meredith, T., \& MacDonald, M. (2017).Communitysupported slum-upgrading: Innovations from Kibera, Nairobi, Kenya. Habitat International, 60,1-9; https://doi.org/10.1016/j.habitatint.2016.12.003

Mohanty M. (2020) Squatter Settlements and Slums and Sustainable Development. In Leal Filho W., Azul A., Brandli L., Özuyar P., Wall T. (Eds.) Sustainable Cities and Communities. Encyclopedia of the UN Sustainable Development Goals. Cham: Springer. https://doi.org/10.1007/978-3-319-71061$7 \quad 49-1$.

Negrusa, A.L., Toader, V., Veronica Rus, R., \& Cosma, S.A. (2016). Study of Perceptions on Cultural Events' Sustainability. Sustainability, 8(12), 1269; https://doi.org/10.3390/su8121269

Nassar, D.M., \& Elsayed, H.G. (2018). From Informal Settlements to sustainable communities. Alexandria Engineering Journal, 57(4),2367-2376; https:// doi.org/10.1016/j.aej.2017.09.004

Obaitor, O.S., Lawanson, T.O., Stellmes, M., \& Lakes, T. (2021). Social Capital: Higher Resilience in Slums in the Lagos Metropolis. Sustainability, 13(7), 3879; https://doi.org/10.3390/su13073879

Ólafsdóttir, R. (2021). The Role of Public Participation for Determining Sustainability Indicators for Arctic Tourism. Sustainability, 13(1), 295; https://doi. org/10.3390/su13010295

Pratomo, R.A., Samsura, D.A.A., \& van der Krabben, E. (2020). Transformation of Local People's Property Rights Induced by New Town Development (Case Studies in Peri-Urban Areas in Indonesia). Land, 9(7), 236; https://doi. org/10.3390/land 9070236

Purwanto, E., Sugiri, A., \& Novian, R. (2017). Determined Slum Upgrading: A Challenge to Participatory Planning in Nanga Bulik, Central Kalimantan, Indonesia. Sustainability, 9(7), 1261; https://doi. org/10.3390/su9071261

Rashid, S.F. (2009). Strategies to Reduce Exclusion among Populations Living in Urban Slum Settlements in Bangladesh. Journal of Health, Population and Nutrition, 27(4), 574-586; https://doi. org/10.3329/jhpn.v27i4.3403

Surya, B., Saleh, H., Suriani, S., Sakti, H.H., Hadijah, H., \& Idris, M. (2020a). Environmental Pollution
Control and Sustainability Management of Slum Settlements in Makassar City, South Sulawesi, Indonesia. Land, 9(9), 279; https://doi.org/10.3390/ land 9090279

Surya, B., Suriani, S., Menne, F., Abubakar, H., Idris, M., Rasyidi, E.S., \& Remmang, H. (2021a). Community Empowerment and Utilization of Renewable Energy: Entrepreneurial Perspective for Community Resilience Based on Sustainable Management of Slum Settlements in Makassar City, Indonesia. Sustainability, 13(6), 3178; https://doi.org/10.3390/ $\underline{\text { su13063178 }}$

Sindleryova, I.B., Garaj, M., \& Dancisinova, L. (2019). Community Planning Perspective and Its Role within the Social Policy of the Municipalities. Social Sciences, 8(6), 183; https://doi.org/10.3390/soc$\underline{\text { sci8060183 }}$

Surya, B., Ahmad, D.N.A., Sakti, H.H., \& Sahban, H. (2020b). Land Use Change, Spatial Interaction, and Sustainable Development in the Metropolitan Urban Areas, South Sulawesi Province, Indonesia. Land, 9(3), 95; https://doi.org/10.3390/land9030095

Samper, J., Shelby, J.A., \& Behary, D. (2020). The Paradox of Informal Settlements Revealed in an ATLAS of Informality: Findings from Mapping Growth in the Most Common Yet Unmapped Forms of Urbanization. Sustainability, 12(22), 9510; https://doi. org/10.3390/su12229510

Surya, B., Hadijah, H., Suriani, S., Baharuddin, B., Fitriyah, A.T., Menne, F., \& Rasyidi, E.S. (2020c). Spatial Transformation of a New City in 20062020: Perspectives on the Spatial Dynamics, Environmental Quality Degradation, and Socio-Economic Sustainability of Local Communities in Makassar City, Indonesia. Land, 9(9), 324; https:// doi.org/10.3390/land9090324

Surya, B., Syafri, S., Hadijah, H., Baharuddin, B., Fitriyah, A.T., \& Sakti, H.H. (2020d). Management of Slum-Based Urban Farming and Economic Empowerment of the Community of Makassar City, South Sulawesi, Indonesia. Sustainability, 12(18), 7324; https://doi.org/10.3390/su12187324

Surya, B., Salim, A., Hernita, H., Suriani, S., Menne, F., \& Rasyidi, E.S. (2021b). Land Use Change, Urban Agglomeration, and Urban Sprawl: A Sustainable Development Perspective of Makassar City, Indonesia. Land, 10(6), 556; https://doi.org/10.3390/ land10060556

Surya, B. (2015a). Spatial Articulation, and Coexistence of Mode of Production In the Dynamics of Development at The Urban Fringe of Makassar City. Journal of Engineering and Applied Sciences, 10 (8), 214-222; https://doi.org/10.36478/jeasci.2015.214.222 
Surya, B., Syafri, S., Sahban, H., \& Sakti, H.H. (2020e). Natural Resource Conservation Based on Community Economic Empowerment: Perspectives on Watershed Management and Slum Settlements in Makassar City, South Sulawesi, Indonesia. Land, 9(4), 104; https://doi.org/10.3390/ land 9040104

Surya, B., Ruslan, M., \& Abubakar, H. 2018. Inequility of Space Reproduction Control and Urban Slum Area Management Sustainability (Case Study: Slum Area of Buloa Urban Village in Makassar City). Journal of Engineering Applied Sciences, 13(15), 6033 - 6042; https://doi.org/10.36478/jeasci.2018.6033.6042

Surya, B. (2015b). Optimization of Function and Role of Traditional Markets in Urban Development System of Ketapang City: a case study: Range Sentap Market, Delta Pawan Subdistrict, Ketapang city'. World Applied Sciences Journal, 33(9), 1457-1471; https:// doi.org/ 10.5829/idosi.wasj.2015.33.09.156111

Surya, B. (2015c). The Dynamics of Spatial Structure and Spatial Pattern Changes at the Fringe Area of
Makassar City. Indonesian Journal of Geography, 47,11-19; https://doi.org/10.22146/ijg.6926

Teferi, Z.A., \& Newman, P. 2017. Slum Regeneration and Sustainability: Applying the Extended Metabolism Model and the SDGs. Sustainability, 9(12), 2273; https://doi.org/10.3390/su9122273

UN-Habitat. 2003. The Challenge of Slums Global Report on Human Settlements. United Nations Human Settlements Programme. London: Earthscan Publications Ltd

Wah Ho, A.F., Zheng, H., Cheong, K.H., Liang En, W., Pek, P.P., Zhao, X., G. Morgan, G., Earnest, A., Qiang Tan, B.Y., Yng Ng, Y., Li Foo, L., \& Hock Ong, M.E. 2020. The Relationship Between Air Pollution and All-Cause Mortality in Singapore. Atmosphere, 11(1), 9; https://doi.org/10.3390/at$\underline{\operatorname{mos} 11010009}$

Zeng, C., Yang, L., \& Dong, J. (2017). Management of urban land expansion in China through intensity assessment: A big data perspective. Journal of Cleaner Production, 153, 637-647; https://doi. org/10.1016/j.jclepro.2016.11.090 